Lucyna Telka*

\title{
Ku autonomii wychowawcy
}

\section{Uwagi wstępne}

Od roku 2000 w Katedrze Pedagogiki Społecznej Uniwersytetu Łódzkiego zachodzi stała współpraca pomiędzy pracownikami placówki dla małego dziecka do 3. roku życia oraz uczelni wyższej. Tym samym realizowana jest istotna przesłanka pedagogiki społecznej wskazująca na związki teorii i praktyki, wzajemną inspirację, możliwość podjęcia namysłu nad działaniami wychowawczymi przez wychowawcę i badacza. Pożytki wynikające z tej współpracy dotyczą użytkowników placówki, czyli małych dzieci, które mogą być tym, kim są w warunkach określonych przez niedyrektywną koncepcję wychowania oraz wychowawców, którzy potrafią respektować wychowanka jako pełnego uczestnika przestrzeni społecznej. Należy podkreślić zmiany dokonane w wewnętrznych przepisach placówki, które sankcjonują zobowiązanie wychowawcy do towarzyszenia dziecku w rozwoju oraz aktywność jednego z pracowników placówki w opracowaniu ogólnopolskich przepisów wprowadzających zawód - wychowawca małego dziecka. Korzyści wynikają także dla studentów, którzy w związku z realizacją celów dydaktycznych mogą obserwować pole praktyki, gdzie realizowana jest niedyrektywna koncepcja wychowania. Efektem współpracy pracowników placówki praktyki i uczelni wyższej są także cykliczne ogólnopolskie seminaria naukowe stanowiące sposobność do spotkania i dzielenia się doświadczeniami.

Teza, która stanowi tu przedmiot analizy, dotyczy poglądu, że autonomiczny wychowawca może towarzyszyć nabywaniu autonomii przez wychowanka. Szczegółowo rozwija ją stanowisko Marie-Agnès Hoffmans-Gosset wskazujące, że ,projekt wychowawcy musi być konfrontowany z projektem wychowanka $[\ldots]$ z tej konfrontacji, negocjacji dwóch oczekiwań wyłania się wspólna treść

\footnotetext{
* Uniwersytet Łódzki, Wydział Nauk o Wychowaniu, Katedra Pedagogiki Społecznej.
} 
wychowania”. Anna Walczak podkreśla wyrażoną powyżej tezę zdaniem: „nie słysząc wezwania wychowanka i nie odpowiadając na nie, a zatem i nie dając siebie, pedagog zamyka nie tylko przed nim drogę urzeczywistniania się, ale zamyka ją również przed samym sobą"2. Pogląd Blaise Ollivier ${ }^{3}$ wskazuje, że autonomia wychowawcy sprzyja tworzeniu warunków do kształtowania autonomii wychowanka. Akceptacja i wspieranie autonomii dziecka, jego kompetencji to umiejętność wychowawcy rozumiana jako rodzaj jego (dorosłego) wolności.

Helena Radlińska ${ }^{4}$, w swoich poglądach na wychowanie dziecka, uwzględnia takie sformułowania jak ,radość dziecięctwa”, „swobodne ćwiczenie sił”, odkrywanie świata przez własną aktywność wychowanka. Wychowawca tworzy warunki dla tej dziecięcej swobody, która w istocie jest trudem w kształtowaniu siebie. Jadwiga Bińczycka ${ }^{5}$ wskazuje, że nadmierna swoboda dziecka zmienia się w anarchię, krzywdzi je, nie pozwala mu poznawać i ustalać granic, rodzi stres i chaos. Nadmierny przymus to opresja, tresura, ogranicza rozwój, powoduje permisywność, uległość.

W pedagogice społecznej wychowanie rozumiane jest jako czynność mentalna wychowawcy - namysł nad projektem działania wychowawczego, który orientuje owo działanie. Wychowanie, według poglądów H. Radlińskiej ${ }^{6}$, „znajduje utajone siły” lub ,hamuje pęd życia”. Wychowawca może sprzyjać wspieraniu wychowanka w nabywaniu autonomii, może też nie dostrzegać oczekiwań, kompetencji dziecka. Poszczególni wychowawcy w placówce mogą różnorodnie realizować swoje podejście do autonomii dziecka, każdy po swojemu. Pojęcie autonomii dziecka może też być wychowawcom nieznane.

Innowacja pedagogiczna, szczegółowo opisana w publikacji Przekształcanie przestrzeni społecznej placówki. Studium społeczno-pedagogiczne na przykładzie żłobków $w^{7}$, realizowana w wielkim mieście w 30 placówkach dla dzieci do 3. roku życia, dokonywała się w wyniku wieloletniej współpracy pracowników placówki wychowania i pedagoga społecznego, badacza z uczelni wyższej. W niniejszym

${ }^{1}$ M.-A. Hoffmans-Gosset, Apprendre l'autonomie. Apprendre la socialisation, Chronique Sociale, Lyon 2000, s. 138.

${ }^{2}$ A. Walczak, Spotkanie z wychowankiem. Ku tożsamości ipse pedagoga, Wydawnictwo Uniwersytetu Łódzkiego, Łódź 2011, s. 154.

${ }^{3}$ B. Ollivier, Autonomie, [w:] J. Barus-Michel, E. Enriquez, A. Levy (red.), Vocabulaire de psychologie. Références et positions, Erés, Ramonville Saint-Agne 2002, s. 58.

${ }^{4} \mathrm{H}$. Radlińska, O wartości życia ludzkiego. (Odczyt wygłoszony w Polskim Radio), Warszawa 1947, s. 2; taż, Rodzina i świat społeczny, Odbitka z „Polskiej Oświaty Pozaszkolnej” 1932, nr 6, Warszawa 1933, s. 5.

${ }^{5}$ J. Bińczycka, Między swobodq a przemocq w wychowaniu, Oficyna Wydawnicza „Impuls”, Kraków 2005, s. 24-30.

${ }^{6}$ Tamże, s. 80.

${ }^{7}$ L. Telka, Przekształcanie przestrzeni społecznej placówki. Studium społeczno-pedagogiczne na przykładzie żłobków, Wydawnictwo Uniwersytetu Łódzkiego, Łódź 2009. 
artykule jest kontekstem dla charakteryzowania procesu kształtowania autonomii wychowawcy, który rozpoczął się od postawienia przez wychowawców pytań: jak jest? jakie działanie wychowawcze podejmują? Odpowiedź przyniosła zarówno krytykę działań dyrektywnych, jak i określenie sił, talentów, umiejętności, ciekawości pracowników, które pozwoliły sformułować kolejne pytania: czy tak ma być nadal? czy może być inaczej? jak inaczej może być?

Helena Radlińska wskazuje, że ,autonomia wychowania [...] podkreśla znaczenie myśli pedagogicznej dla wszystkich spraw zachodzących między ludźmi”, by „korzystać z walorów najtrwalszych i rzutować w przyszłość”. Będąc w zgodzie ze stanowiskiem pedagogiki społecznej na temat wychowania, badacz wprowadził do poznawania, wspólnie z wychowawcami w placówce dla małego dziecka, propozycję niedyrektywnej koncepcji wychowania, towarzyszenia w rozwoju, która spełnia, jak się wydaje, powyższe kryteria.

\section{Przekształcanie}

W pedagogice społecznej odnaleźć można inspiracje do przekształcania zastanej rzeczywistości. Jedną z nich jest słowo „niezadowolenie”, wprowadzone przez H. Radlińską , niezadowolenie z sytuacji, gdy za dziecko, za dorosłego myślą inni ludzie ${ }^{10}$. Słowo „niezadowolenie” stanowi zachętę do „zatrzymania się", by poddać analizie zdarzenie, które uznawane jest za oczywiste, ponieważ „tak było, tak jest i tak będzie”. Niezgoda sprzyja postawieniu pytań: dlaczego tak jest? czy tak musi być? Zachęca do pytania o zmianę sytuacji: co, dlaczego, jak, kto może zmieniać? W poglądach pedagogów społecznych próba odpowiedzi na powyższe pytania pozwala przywołać termin ,przekształcanie”. Przekształcanie w odniesieniu do spraw wychowania to zmiana "sposobu patrzenia na dziecko" To czyn, uczenie się, by przebyć drogę „od emancypacyjnych haseł do opanowania sztuki dialogu międzygeneracyjnego" 12 .

Termin „przekształcanie” określa proces długotrwały, złożony, dotyczący środowiska niewidzialnego. Na podstawie kilkuletniej współpracy wychowawców i badacza można powiedzieć, że przekształcanie daje nadzieję na długotrwały, ale owocny proces urzeczywistniania w życiu społecznym takich wartości jak wolność, autonomia, szacunek, twórczość, zaufanie, które ujawniają się

${ }^{8}$ H. Radlińska, Pedagogika społeczna, Ossolineum, Wrocław-Warszawa-Kraków 1961, s. 81.

${ }^{9}$ Tamże, s. 49.

${ }^{10} \mathrm{D}$. Gribble, Edukacja w wolności. W poszukiwaniu idealnego systemu ksztatcenia, Oficyna Wydawnicza „Impuls”, Poznań-Kraków 2005, s. 136.

${ }^{11}$ J. Bińczycka, Korczakowska pedagogika emancypacyjna, [w:] B. Śliwerski (red.), Nowe konteksty (dla) edukacji alternatywnej XXI wieku. Idee - Metody - Inspiracje, Oficyna Wydawnicza „Impuls”, Kraków 2001, s. 611; L. Telka, Przekształcanie przestrzeni społecznej placówki...

${ }_{12}$ J. Bińczycka, Korczakowska pedagogika emancypacyjna, s. 614. 
w aktywności wychowawcy i wychowanka. Celem przekształcania, w przywołanym przykładzie placówki dla dziecka do 3. roku życia, stała się emancypacja wychowawców od wcześniejszych wyobrażeń o wychowaniu (dyrektywność), by mogli kształtować intelektualną autonomię, by przekształcali wcześniejsze przekonania o wychowaniu i dokonywali swoistego „przejścia” do nowych wyobrażeń o swoim warsztacie pracy oraz relacjach wychowawcy i wychowanka (ku niedyrektywności). Wcześniejsze bowiem wyobrażenia o wychowaniu określały wychowawcę małego dziecka jako centralną postać relacji z nim, która planuje, kieruje, przekazuje, uczy, kontroluje, oczekuje na efekt, pracuje z grupą małych dzieci, oddalona od każdego dziecka z osobna. Nowe wyobrażenia o wychowaniu odwoływały się do stanowiska pedagogiki społecznej wobec wychowania - koncepcji towarzyszenia w rozwoju.

Przekształcanie wyobrażeń w kierunku od dyrektywności do niedyrektywności $\mathrm{w}$ relacjach $\mathrm{z}$ wychowankiem, stanowi proces długotrwały, zorientowany na odkrywanie przez wychowawców wolności, szacunku, zaufania, wyobraźni, wrażliwości na detale w relacji z dzieckiem. Przekształcanie to wprowadzanie w toku innowacji pedagogicznej w placówce takich elementów warsztatu pracy wychowawcy (np. czytanie, pisanie, dyskutowanie, obserwacja, projektowanie), które sprzyjają wytężonemu rozpoznawaniu praktyki wychowania oraz teoretycznych nurtów myślenia o wychowaniu przez jego uczestników. Społeczno-pedagogiczny wymiar przekształcania, charakteryzowany z perspektywy pedagogiki społecznej, odnosi się do pracy z ludźmi, dla ludzi, wobec ludzi. Uczestnikami tego procesu są przede wszystkim wychowawcy. Badacz w pierwszym roku współpracy z wychowawcami ,dawał” informacje o tym, jak działają pracownicy, jakie kwestie teoretyczne warto poznawać. W kolejnych latach stawał się współuczestnikiem analizowania pola praktyki. W ostatnim roku współpracy ,z oddali”, ale uważnie, był pierwszym czytelnikiem opracowywanych przez wychowawców projektów pedagogicznych. Celem przekształcania wyobrażeń o działaniu wychowawczym jest emancypacja wychowawcy i kształtowanie autonomii.

Autonomia wychowawcy może sprzyjać uwalnianiu się od oczekiwania gotowych odpowiedzi dotyczących propozycji rozwiązywania różnorodnych problemów codziennego życia w placówce. Na przykład spostrzeżenie wychowawcy, że liczna grupa dzieci ma umyć ręce przed posiłkiem może wywoływać dyrektywność, obawy o czas trwania tej czynności (obiad wystygnie), bezpieczeństwo dzieci, oczekiwanie „recepty” na rozwiązanie tej kwestii. Może jednakże spowodować odwołanie się wychowawcy do warsztatu metodologicznego, który opracowywany był w toku innowacji w placówce - umiejętności przygotowania się do obserwowania sytuacji stwarzających problem, rozmowy z innymi wychowawcami, zorganizowania spotkania, by wspólnie poddać analizie zgromadzone informacje, sformułować propozycje rozwiązania problemu. Autonomia wychowawcy 
nie pozostawia go bezradnym czy biernym wobec spraw wychowania, lecz umożliwia aktywność intelektualną i emocjonalną wspólnie z innymi.

Bohdan Cyrański ${ }^{13}$ poddaje analizie aksjologiczne podstawy pedagogiki społecznej H. Radlińskiej, w której, według autora, wykształcenie i „działalność oświatowa" mają znaczenie dla wspierania rozwoju człowieka, oczywiście także wychowawcy, w jego rozumieniu świata i aktywności w nim. Analiza wyników badań podjętych przez autora wskazuje wymagania wobec wychowawcy, takie jak „kształcenie”, „wysiłek osobisty”, „demokracja”"14. Te trzy terminy mogą opisywać wychowawcę twórczo zaangażowanego w przekształcanie środowiska życia, zdolnego „do kierowania sobą w sposób odpowiedzialny”"15 oraz, jak dodaje autor, samodzielnie myślącego, wątpiącego, rozważającego, refleksyjnego ${ }^{16}$. Istotność wskazanych cech aktywności wychowawcy podkreśla stanowisko A. Walczak, która zaznacza, że wychowawca powinien się zastanawiać, jak „,nie pogłębiać inności wychowanka w jej negatywnych aspektach" ${ }^{17}$ oraz jak darzyć go szacunkiem.

\section{Dziecko}

Helena Radlińska, charakteryzując zadania wychowawcy, podkreśla, że tworzy on warunki rozwoju wychowanka, podejmuje odpowiedzialność wychowania dzieci, a tym samym podejmuje zobowiązanie pracy nad sobą. Autorka zaznacza, że „nie dla nas wychowujemy dzieci”, „musimy je wyposażyć do pójścia w świat"18 usamodzielniać. Dodaje również, że dorosłym daje szczęście śledzenie i pielęgnowanie rozwoju wychowanka. W poglądach $\mathrm{H}$. Radlińskiej na temat wychowania dziecka uwydatnia się potrzeba tworzenia, zdobywania wiedzy przez własną aktywność wychowanka. W związku z tym dziecko oczekuje stałości, ciągłości, przewidywalności poczynań wychowawcy, czyli określonego porządku ${ }^{19}$, reguł, które ten porządek wskazują. Pragnie ono jednocześnie swobody dla własnej aktywności. Swoboda, w świetle analiz dokonanych przez E. Muszyńską ${ }^{20}$, zdaje się być bardzo wymagającym sposobem bycia, bowiem wyraża się w działaniach, uczuciach, myśleniu, woli człowieka. Swoboda to wysiłek intelektualny,

${ }^{13}$ B. Cyrański, Aksjologiczne podstawy pedagogiki Heleny Radlińskiej. Przykład zastosowania interpretacji hermeneutycznej, Wydawnictwo Uniwersytetu Łódzkiego, Łódź 2012, s. 75-76.

${ }^{14}$ Tamże, s. 82.

${ }^{15}$ Tamże, s. 83.

${ }^{16}$ Tamże, s. 122-123.

${ }^{17}$ A. Walczak, Spotkanie z wychowankiem ..., s. 152-153.

${ }^{18}$ H. Radlińska, Pedagogika społeczna, s. 82.

${ }^{19}$ M. Kolankiewicz (red.), Pielęgnacja niemowlat i małych dzieci w placówkach opiekuńczych, Dom Małych Dzieci im. Ks. G. P. Baudouina i Wydawnictwo „Żak”, Warszawa 1998, s. 24-25.

${ }^{20}$ E. Muszyńska, Swoboda, przymus i przemoc w relacjach dziecko-dorosty, Wydawnictwo Naukowe UAM, Poznań 1998, s. 46-52. 
emocjonalny, działaniowy, uwzględniający uzgadnianie pól wolności z innymi. Jadwiga Bińczycka ${ }^{21}$ odwołuje się do myśli pedagogicznej J. Korczaka, by podkreślić emancypacyjny wymiar jego poglądów, przekonanie, że wychowanek jest kompetentnym uczestnikiem relacji z wychowawcą. Emancypacja dziecka, możliwość kształtowania przez nie autonomii wymaga gotowości wychowawcy do zaakceptowania jego prawa do bycia podmiotem. Wymaga zatem emancypacji samego wychowawcy, by nie zawłaszczał, lecz szanował, poznawał dziecięcą ciekawość, wyobraźnię, poczucie sprawstwa, powstające pomysły na aktywność. Wymaga akceptacji dla dziecięcego ,nicnierobienia”, wyglądania przez okno, obserwowania przez dziecko innych dzieci i podążania za ich aktywnością, bycia inspiracją dla aktywności innych dzieci. Wymaga zgody na uczestniczenie dziecka w różnorodności sytuacji społecznych, nie tylko z wychowawcą i na usankcjonowaną samotność wychowanka, gdy koncentruje się na czymś.

Przywołanie przykładów praktyki dotyczących placówek dla małego dziecka w Reggio Emilia i San Miniato ujawnia, że w wyobrażeniach wychowawcy dziecko jest „pełne potencjału, silne, kompetentne”, ,aktywne i zdolne do poszukiwania, eksperymentowania"22. Wychowawca tworzy warunki, by mogło urzeczywistniać ciekawość, badanie świata samemu i z innymi. Środowisko traktowane jest jako nauczyciel ${ }^{23}$.

David Gribble w publikacji noszącej tytuł znamienny również dla niniejszego artykułu-Edukacja w wolności-opisuje placówki, w których wychowawcy podjęli projekt wspierania autonomii wychowanków. Uczenie się dzieci charakteryzowane jest jako proces niewymuszony, inspirowany ciekawością, tym, co interesuje, obserwowaniem, rozmowami, aktywnością w samotności i z innymi. Nie wiąże się to z nieograniczonym robieniem tego, co się podoba. Dzieci uczą się reguł, a także je stanowią. Uczą się myśleć za siebie, stają się rozważne, pewne siebie, umieją się troszczyć o innych ${ }^{24}$. Podkreślane jest, by dziecko podążało za tym, co je ciekawi, by ufało sobie, by czerpało przyjemność z aktywności, uczenia się ${ }^{25}$. Relacje dorosłego i dziecka są w tych placówkach kształtowane bardziej na „bazie sympatii niż szacunku”, której w sposób naturalny „towarzyszy głęboki i trwały szacunek"26. Analiza edukacji w wolności, dokonana przez D. Gribble'a na podstawie charakterystyki szkół alternatywnych, wskazuje ważną cechę

${ }^{21}$ J. Bińczycka, Korczakowska pedagogika emancypacyjna, s. 612.

${ }^{22}$ M. Pacholczyk, Edukacja w żłobkach w San Miniato jako przestrzeń rozwoju społecznego dzieci oraz wspótpracy z rodzicami i środowiskiem lokalnym, „Problemy Wczesnej Edukacji” 2012, nr 4; A. Maj, Koncepcja edukacji przedszkolnej w Reggio Emilia we Włoszech, [w:] Z. Melosik, B. Śliwerski (red.), Edukacja alternatywna w XXI wieku, Oficyna Wydawnicza „Impuls”, PoznańKraków 2010, s. 167.

${ }^{23}$ A. Maj, Koncepcja edukacji przedszkolnej..., s. 168.

${ }^{24}$ D. Gribble, Edukacja w wolności..., s. 137.

${ }^{25}$ Tamże, s. 157.

${ }^{26}$ Tamże, s. 156. 
poglądów pedagogicznych ich twórców. Uznają oni, że głównym wychowawcą jest przede wszystkim środowisko społeczne, które charakteryzuje dynamika i różnorodność relacji społecznych, waga decyzji, pomysłów, wyborów dzieci. Dorosły jest obok. Wychowawca odkrywa, że nie jest jedynym źródłem wiadomości, pomysłów na aktywność dla wychowanka. Pogląd ten niesie w praktyce warunki sprzyjające wolności wyborów dokonywanych przez dzieci, różnorodność dróg edukacyjnych, różnorodność relacji, zwłaszcza pomiędzy wychowankami, uczenie się od siebie nawzajem. Wychowawca nie narzuca się, ale jest „zainteresowany i interesujący”.

Analiza spostrzeżeń Francisa Imberta $^{27}$ na temat napięć, jakie mają miejsce w przestrzeni placówki, pokazuje zagrożenia dla kształtowania autonomii wychowanka, sprzeczność pomiędzy aktywnością dziecka w relacji z wychowawcą (w klasie szkolnej), uległość wobec reguł przez niego narzucanych a aktywnością dziecka poza wpływem dorosłego, ale na terenie placówki (na podwórku szkolnym). Autor wskazuje dwa porządki przeżywane przez tego samego wychowanka w tej samej placówce. Porządek konformistyczny dokonuje się w relacji dziecka i dorosłego, wyzwala defensywne strategie wychowanka. Uległość dziecka, jego podporządkowanie się propozycjom wychowawcy uspokaja wychowawcę. Porządek wolnościowy dokonuje się poza obecnością wychowawcy, wyzwala ofensywne strategie wychowanka wspólnie z innymi dziećmi. Autor ukazuje kompetencje dziecka - intelektualne, emocjonalne, społeczne do kształtowania, chronienia porządku wolnościowego. Wskazuje na zróżnicowanie przestrzeni placówki, w których dziecko przebywa niemal równocześnie i w związku z tym realizuje różne strategie aktywności, by dawać sobie radę z przestrzenią centralną, formalną, konserwującą oraz peryferyjną, nieformalną, wolnościową. Autor podkreśla, że pojawiające się napięcia pomiędzy nimi dziecko stara się przekroczyć, spożytkowując swoje kompetencje na rzecz przetrwania, dostosowania się, bierności, uległości, defensywności, niezgody, ofensywności, krytyki, buntu.

\section{Emancypacja}

Koncepcja dyrektywnego działania w wychowaniu w istocie, co wskazuja wyniki wieloletnich badań w placówce dla małego dziecka ${ }^{28}$, unieruchamia aktywność wychowanka i wychowawcy. Zamyka wychowawcę w dobrze poznanych ,korytarzach” rutyny, powtarzalności, odtwarzania tych samych czynności. Emancypacja dotyczy wyzwolenia od przekonania, że przyjęta i realizowana koncepcja wychowania jest jedyną, możliwą. Przede wszystkim jednak dotyczy

${ }^{27} \mathrm{~F}$. Imbert, Vers une clinique du pédagogie. Un itinéraire en science de l'éducation, Éditions Matrice, Vigneux 1992, s. 21-24.

${ }^{28}$ L. Telka, Przeksztatcanie przestrzeni społecznej placówki... 
dekonstrukcji twierdzenia, że dyrektywna koncepcja wychowania jest sprzyjająca rozwojowi dziecka. Dyrektywna koncepcja wychowania była podzielana przez pracowników placówki, jej realizacja była oczekiwana przez kierownictwo, a także przez rodziców. Wychowawca pozbawiony sposobności rewidowania swoich poglądów odnosił się do pewności - tak się robiło zawsze, tak nas uczono. Dyrektywność działania wychowawczego oddala wychowawcę i wychowanka od siebie, umożliwia przede wszystkim aktywność wychowawcy wobec wszystkich dzieci - jednakową dla wszystkich, zorganizowaną przez dorosłego. Wychowawcy mają przekonanie, że wiedzą, czego warto dziecko uczyć, co jest mu przydatne. Nie rewidują swoich przekonań. Trzeba zaznaczyć, że są przygotowani do swoich działań, np. wykorzystują scenariusze zajęć z dziećmi, w których przewidziane są pomoce, zabawki, teksty piosenek i wierszy.

Analizowanie własnych działań dokonywane przez wychowawców wspólnie z zaproszonym do współpracy badaczem, w odniesieniu do określonej niedyrektywnej koncepcji wychowania, pozwalało im nabierać odwagi do uwalniania się od dotychczasowych przekonań na temat wychowania, oduczania się tego, co „stare”, dyrektywne, do emancypowania siebie, by kształtować autonomię. B. Ollivier zaznacza, że autonomia wychowawcy może się przejawiać, gdy „nie wierzy w rozwiązania bez alternatyw" ${ }^{\prime 29}$, gdy podejmuje się odkrywania iluzji swojej niezbędności dla wychowanka ${ }^{30}$.

Emancypacja jest procesem umożliwiającym kształtowanie autonomii ${ }^{31}$. Jej istota jest „poparta działaniem samodzielna refleksja”32. Katarzyna Szumlewicz zaznacza, by ,procesy jej wywoływania nie okazały się kolejną inwazją, tyle że ze szlachetną intencją" ${ }^{3}$. Emancypowanie się wychowawcy pozwala być aktywnym - pytać, wyrażać niezgodę, podawać w wątpliwość, szukać rozwiązań, dostrzegać dotychczasowe ograniczenia działań wychowawczych, analizować zależność wychowawcy od stereotypów zwalniających wychowawcę od rozumienia świata ${ }^{34}$, od presji rodziców, od presji warunków życia dziecka w rodzinie.

Kwestia emancypacji wychowawcy od tego, co opresyjne, przesycone rutyną dotyczy dekonstruowania sposobu myślenia o wcześniejszych działaniach, a następnie rekonstruowania koncepcji wychowania, która pozwala:

- uwolnić siebie i dziecko z ograniczeń dyrektywności;

- rozpoznać inną możliwość myślenia o wychowaniu;

${ }^{29}$ B. Ollivier, Autonomie, s. 58.

${ }^{30}$ H. Radlińska, Pedagogika społeczna, s. 82-83; B. Ollivier, Autonomie, s. 57.

${ }^{31} \mathrm{~K}$. Szumlewicz, Emancypacja przez wychowanie, czyli edukacja do wolności, równości i szczęścia, GWP, Sopot 2011, s. 15.

${ }^{32}$ Tamże, s. 366.

${ }^{33}$ Tamże.

${ }^{34} \mathrm{~W}$. Woronowicz, Podstawy refleksyjne edukacji opiekuńczo-wychowawczej, Wyższa Szkoła Pedagogiczna, Słupsk 1998, s. 63. 
- ciężko pracować nad przekształcaniem swoich wyobrażeń o wychowaniu;

- pracować wspólnie z innymi;

- odkrywać mechanizmy obronne i je przekraczać35.

Innowacja pedagogiczna realizowana we współpracy wychowawców i badacza charakteryzuje się swoistą czasoprzestrzenią - czas przed, podczas i po innowacji, w którym spotykali się ze sobą ludzie, by rozmawiać, gromadzić informacje, analizować je, myśleć głośno, wspólnie analizować praktykę wychowania. Wskazane działania można uznać za czynniki emancypacji wychowawców, ale także procesu ujawniającego konflikty i kryzysy.

Początek współpracy badacza i wychowawców w placówce wywołał konflikt pomiędzy dwiema perspektywami tworzenia warunków dla pobytu dziecka w żłobku, pomiędzy realizowaną dyrektywnością działań wychowawców i niedyrektywnością jako propozycją do rozważenia. Konflikt spowodował kryzys pomiędzy przekonaniami wcześniejszymi a proponowanym kierunkiem ich zmiany. Towarzyszenie $\mathrm{w}$ rozwoju to koncepcja wychowania, która pozwala przywołać wizję świata odwołującego się do szacunku, zaufania, wolności - wartości nie zawsze obserwowanych w rzeczywistości placówek wychowania, mimo deklaracji wychowawców.

Wskazać jednak należy, że proponowana przez badacza niedyrektywna koncepcja wychowania nie stanowiła „nowości” dla niektórych wychowawców. Już M.-A. Hoffmans-Gosset ${ }^{36}$ zwraca uwagę, że w placówce wychowania są wychowawcy, którzy podejmują realizację celu, jakim jest troska o autonomię wychowanka. Jednak są oni odosobnieni lub nawet izolowani. W toku analizy zdarzeń związanych $\mathrm{z}$ innowacją pedagogiczną ujawnione zostały $\mathrm{w}$ pracy niektórych wychowawców przejawy specyficznych, odmiennych od powszechnie realizowanej w placówkach dyrektywności, działań niedyrektywnych, wspierających aktywność dziecka, jego ciekawość, pomysły w badaniu otoczenia. Wskazani wychowawcy nie nazywali swoich działań specyficznymi, nie podejmowali starań, by je propagować, z ich perspektywy poznawać swoje relacje z dzieckiem. Stanowili siły ludzkie dla realizowanej innowacji pedagogicznej ${ }^{37}$.

Autonomia dziecka początkowo została odczytana jako zagrożenie dla wychowawcy, dla jego przydatności w procesie wychowania. Była artykułowana przez wychowawców jako niepewność, pytanie, „co mamy robić”, gdy dziecko bawi się swobodnie, samodzielnie. Autonomia wychowawcy przejawia się w jego decyzji o akceptacji autonomii drugiego człowieka i podejmowaniu działań gwarantujących warunki jej kształtowania przez wychowanka ${ }^{38}$.

\footnotetext{
${ }^{35}$ L. Telka, Przekształcanie przestrzeni społecznej placówki...

${ }^{36}$ M.-A. Hoffmans-Gosset, Apprendre l'autonomie..., s. 67.

${ }^{37}$ L. Telka, Przekształcanie przestrzeni społecznej placówki..., s. 154-155.

${ }^{38}$ M.-A. Hoffmans-Gosset, Apprendre l'autonomie..., s. 157.
} 


\section{Autonomia wychowawcy - proces}

M.-A. Hoffmans-Gosset ${ }^{39}$ wyraża pogląd, że żadna osoba nie może dać autonomii innej osobie. Autonomicznym człowiek się staje. Nikt nie może nauczyć autonomii. Ucząc się jej, można stawać się autonomicznym. Istotą stawania się autonomicznym są relacje z innymi ludźmi. Autonomia to wartość, która pozwala jednostce stać się odpowiedzialną ${ }^{40}$.

Trzeba postawić pytanie: co to znaczy - autonomia wychowawcy działającego w polu praktyki? $\mathrm{Na}$ podstawie analizy wyników badań prezentowanych w publikacji Przeksztatcanie przestrzeni społecznej placówki... można wskazać, że autonomia wychowawcy oznacza stały wysiłek, by rozmawiać, czytać, pisać, słuchać, by przygotowywać narzędzia poznawania własnej praktyki i je stosować. Oznacza również kształtowanie postawy czynnej, by myśleć o sobie inaczej niż wcześniej, uczyć się być wśród innych ludzi. Kształtowanie autonomii to praca angażująca, wymagająca, bo się chce.

Autonomia wychowawcy nie jest niezależnością. W pedagogice społecznej przesłanki autonomii wychowawcy odnaleźć można w charakteryzowaniu wychowania jako dziedziny twórczości, w podkreślaniu postawy czynnej człowieka zdolnego do działania. Autonomia wychowawcy odnosi się do zobowiązania, do uzgadniania (negocjowania, mediowania, projektowania) wspólnie z innymi wychowawcami w placówce podzielanej koncepcji wychowania. Ważne jest również zobowiązanie do poddawania refleksji przyjętej koncepcji wychowania w odniesieniu do oczekiwań wychowanka, w stałym odniesieniu do praktyki. Zatem autonomia wychowawcy wyraża się w rozważaniu, kwestionowaniu, ocenianiu, poświęcaniu uwagi zdarzeniom z pola praktyki, by gwarantować warunki wspierania autonomii wychowanka.

Zmiany - rozważenie i przyjęcie przez wychowawców niedyrektywnej koncepcji wychowania - towarzyszenia w rozwoju dziecka - rozpoczęły się „od dziecka". Wychowawcy, w toku analizowania swoich działań wychowawczych wspólnie z badaczem, odnosili się zawsze do pola praktyki, do sytuacji, które dotyczyły dziecka. Pierwsze zmiany - na przykład przestawienie kilku stołów z jadalni do innego pomieszczenia ujawniło, że posiłek nie musi przebiegać w tłoku, hałasie, pośpiechu, napięciu, że posiłek wystygnie, że któreś dziecko nie otrzyma pomocy w jedzeniu. Prosty wydawałoby się zabieg - możliwość spożywania posiłku przez dzieci w dwóch pomieszczeniach - nie był prosty, wymagał bowiem podjęcia decyzji, wywołał zdumienie wychowawców, że nie ma hałasu, że nie trzeba się spieszyć, że miały miejsce ciekawe rozmowy pomiędzy dziećmi,

${ }^{39}$ Tamże, s. 117.

${ }^{40}$ A. Petiau, L. Pourtau, Une autonomie polysémique. Réflexion á partir d'une rechercheaction sur l'accès aux droit et aux soins des squatters, „Vie Sociale” 2012, nr 1, Autonomie et contrôle social. Mythe et réalité, s. 99. 
był czas na „badanie” potraw na talerzu, spokój i zadowolenie. Wychowawcy odkrywali dziecko, kształtowali nowe przekonania o nim. Zostało ono zostało dostrzeżone jako osoba, która:

- aktywnie uczestniczy w relacji z wychowawca, kształtuje relację;

- przekazuje wychowawcy liczne informacje, które warto/trzeba dostrzec i zrozumieć;

- uczestniczy w relacji wymiany;

- jest inspirująca dla wychowawcy;

- jest kompetentna.

Kazimierz Obuchowski ${ }^{41}$ w publikacji Od przedmiotu do podmiotu charakteryzuje ludzi myślących i zaangażowanych, twórczych i wykształconych, którzy są zdolni do odkrywania siebie i własnej odpowiedzialności. W toku innowacji wychowawcy rozpoznawali niedyrektywne przesłanki myślenia o wychowaniu, orientowali swoje przekonania ku wspieraniu autonomii wychowanka jako czynnika pomyślnego rozwoju małego dziecka.

Wychowawcy, analizując swoje działania wychowawcze, zmierzali się z tym, co dotychczas było słuszne, dobre, co obowiazzywało, co było wymagane, oczekiwane, czemu nadawano sens, co decydowało o dyrektywności działania. Podejmowali działania dla „dobra dziecka”, które uczestniczyło w związku $\mathrm{z}$ tym $\mathrm{w}$ zaplanowanych, zorganizowanych, kierowanych zajęciach, licznych, długotrwałych, także ponad swoją miarę i możliwości. Wyniki badań dotyczące nauczycieli, prezentowane przez Henrykę Kwiatkowską ${ }^{42}$, ujawniają ich zorientowanie na wykonywanie powinności, czynienie dobra, jednak bez poszukiwania uzasadnień dla uprawomocnienia tych przekonań. Termin „dobro dziecka” nie był poddawany analizie przez wychowawców w żłobku, raczej uspokajał, pozwalał sankcjonować powtarzalność znanego porządku. Jego sens ujawniał się w aktywizmie wychowawców, nadmiernym przygotowaniu do zajęć z dziećmi, sytuowaniu się w centrum różnorodnych sytuacji społeczno-wychowawczych, takich jak zabawa, rysowanie, toaleta. Wychowawcy, nadmiernie skoncentrowani na sobie, nie dostrzegali dystansu pomiędzy sobą, swoimi pomysłami na organizowanie aktywności a oczekiwaniami dzieci oraz wiedzą naukową.

Autonomia to wyzwalanie się wychowawcy z wcześniejszych przekonań o relacjach z dzieckiem, podejmowanie decyzji o zerwaniu z ograniczeniami dyrektywności, opowiedzenie się za wspieraniem autonomii wychowanka, rozważanie przyjęcia innej koncepcji wychowania, uczenie się jak uwalniać dziecko ze swoich poglądów, to dokonanie wyboru na rzecz bycia wychowawcą podejmującym pracę nad sobą, by czynić swoją wrażliwość i wyobraźnię bogatą

${ }^{41}$ K. Obuchowski, Od przedmiotu do podmiotu, Akademia Bydgoska, Bydgoszcz 2001, s. $13-16$.

${ }^{42}$ H. Kwiatkowska, Tożsamość nauczycieli. Między anomiq i autonomiq, GWP, Gdańsk 2005, s. $230-231$. 
i pobudzona, pozwalającą dostrzegać szczegóły, detale w aktywności dziecka, we wzajemnych z nim relacjach, które pozwolą podejmować działanie lub powstrzymać się od interwencji.

W toku współpracy z badaczem pracownicy placówki stanęli wobec podjęcia decyzji o podejmowaniu „codziennego trudu” dokonywania refleksji przed, podczas i po działaniu, by każdorazowo podczas spotkania z wychowankiem być zdolnym do odpowiadania na jego oczekiwania, możliwości, trudności oraz, by podczas spotkania z wychowawcami być zdolnym do analizy zdarzeń z pola praktyki. Autonomia to określony sposób bycia wśród ludzi, z ludźmi, dla ludzi. M.-A. Hoffmans-Gosset ${ }^{43}$ wskazuje na „ducha zespołu”, „ducha podzielania". Proponowane przez B. Ollivier rozumienie autonomii wychowawcy wskazuje, że jest ona „zorientowana na tworzenie relacji społecznych innych niż te już utworzone" ${ }^{\prime 4}$. Autonomia wychowawcy ma wymiar relacyjny, wspólnotowy, pozwala „liczyć na siebie i na innych" ${ }^{45}$. Pozwala prowadzić intensywne życie społeczne wychowawców w placówce, dotyczące spraw wychowania, np.: angażowanie się w badanie-działanie, odkrywanie problemów praktyki wychowania, artykułowanie ich, spotkania zespołu pedagogicznego, by o nich rozmawiać, poszukiwać rozwiązań. Wieloletni proces realizowania innowacji pedagogicznej przyniósł różnorodne możliwości uprawiania demokratycznych form komunikowania się, symbolicznej wymiany, mediacji, takich jak: przestrzeń edukacyjna, zespół pedagogiczny podejmujący sprawy wychowania, opracowywanie projektu pedagogicznego w każdym żłobku, pojmowanie obserwacji jako sposobu bycia wychowawcy.

\section{Wychowawca}

Dlaczego czas, praca badacza i wychowawców zorientowane były ku autonomii wychowawcy? Kształtowanie autonomii przez jednostkę jest procesem wpisanym w całe jej życie. Stanowi wysiłek intelektualny i emocjonalny, pracę nad sobą dokonującą się w relacjach z innymi. Namysł nad wychowaniem przyniósł pracownikom placówki odkrycie - wychowawca „unieruchomiony" w znanym sobie poglądzie na wychowanie, w stosowanej metodyce, unieruchamia w nich także wychowanka. Namysł nad wychowaniem z punktu widzenia koncepcji towarzyszenia w rozwoju pozwalał pobudzać wrażliwość i niezgodę wychowawcy na przejawy uległości, zależności, podporządkowania wychowanka. Zwracał jego uwagę na dominację, urabianie, kierowanie wychowankiem.

\footnotetext{
${ }^{43}$ M.-A. Hoffmans-Gosset, Apprendre l'autonomie..., s. 138.

${ }^{44}$ B. Ollivier, Autonomie, s. 57.

${ }^{45}$ Tamże.
} 
Analiza poglądów M.-A. Hoffmans-Gosset ${ }^{46}$ ujawnia, że rozważanie autonomii jednostki wymaga uwzględnienia takich terminów, jak: Ja, prawo, sumienie, wartości, afektywność, wybór, odpowiedzialność, relacje społeczne, komunikacja. Autonomia dziecka może być przez nie kształtowana, gdy wychowawca tworzy warunki dla jej urzeczywistniania. Wychowawcy poznawali niedyrektywną koncepcję wychowania, którą uczyli się podzielać, artykułować w projekcie pedagogicznym, dokumencie obowiązującym z czasem w placówce, narzędziu orientującym działanie wychowawcze, uczyli się prowadzić wspólne zawodowe życie społeczne (spotykali się, dyskutowali), kształtowali wrażliwość i wyobraźnię społeczną. Wychowawcy kształtowali swoją zgodę na emancypację i autonomię wychowanka oraz niezgodę na jej zagrożenia, odkrywali w sobie odwagę, by rozpoznawać, poddawać ocenie i nazywać krytycznie to, co orientowało ich działanie wcześniej, mianowicie dyrektywność. Odkrywali chaos w swoim myśleniu o działaniu w toku uczenia się nowej, niedyrektywnej koncepcji wychowania i oduczania się dotychczasowej, podejmowali wysiłek, by nie dopuścić do jego ujawnienia się w polu praktyki, w toku zmian.

Przekształcanie przestrzeni społecznej placówki dotyczyło tego, co niewidzialne. Sprzyjało tworzeniu takich narzędzi pracy wychowawcy, by „zobaczyć”, poznawać, analizować dotychczasowe działania wychowawcze, jak też podawać w wątpliwość proponowana, niedyrektywną koncepcję wychowania. Wychowawcy „przebyli drogę” od niedostatku pytań o realizowane działania wychowawcze, bez niezgody na ich dyrektywność, nieujawnianie swej niezgody, zależność od rutyny, przyzwyczajeń, niedostatku wiedzy teoretycznej, do zadawania pytań, podważania porządku, odwagi, stawania się niezależnym od własnych obaw, emocji, władzy innych (np. wyobrażonej władzy rodziców), do przyjemności uczenia się. To, co znamionuje proces przekształcania można przedstawić następująco: oduczanie się - dekonstruowanie dotychczasowych wyobrażeń o wychowaniu, uczenie się - konstruowanie, kształtowanie nowych wyobrażeń o wychowaniu ${ }^{47}$.

Paweł Rudnicki ${ }^{48}$ podkreśla, że uczenie się ma wymiar wyzwalający, bowiem stanowi czynnik silnie wspomagający, dotyczy nabywania świadomości o sobie, o swojej rzeczywistości, pozwala na odkrywanie mechanizmów ograniczenia człowieka, wychowanka, wychowawcy, pozwala odmienić swój sposób myślenia, zachęca, by szukać możliwości wyzwolenia się z wcześniej stworzonego i zaakceptowanego świata, umożliwia czytanie, słuchanie, myślenie, rozmowę. Wychowawca małego dziecka, zaangażowany uczestnik innowacji pedagogicznej, potrafił podjąć wysiłek, by wyjść poza schematy, w których dotychczas uczestniczył,

${ }^{46}$ M.-A. Hoffmans-Gosset, Apprendre l'autonomie..., s. 16.

${ }^{47}$ L. Telka, Przekształcanie przestrzeni społecznej placówki..., s. 200.

${ }^{48}$ P. Rudnicki, Oblicza buntu w biografiach kontestatorów: refleksyjność, wyzwalajace uczenie się, zmiana, Wydawnictwo Naukowe Dolnośląskiej Szkoły Wyższej, Wrocław 2009, s. 254-266. 
umiał interpretować rzeczywistość i wiedzę teoretyczna, by kształtować wrażliwość na problemy w polu praktyki, wzbogacać język dla jej analizowania i rozumienia, kształtować filozofię działania wychowawczego.

Badanie-działanie stało się propozycją wspólnego zaangażowania wychowawców i badacza w uczenie się, by przekształcać myślenie o wychowaniu. Badanie-działanie to badania partycypacyjne, aktywizujące, pozwalają uczestnikom odnaleźć odwagę do „wzięcia spraw w swoje ręce”, wyzwalają poczucie sprawstwa. Badanie-działanie to badania komunikacyjne ${ }^{49}$, podczas których komunikacja, ekspresja swoich poglądów, słuchanie sprzyjają uczeniu się, także przyjmowaniu roli ucznia ${ }^{50}$. Wychowawcy, stając się współrealizatorami tej metody badań, mogą kształtować swoją autonomię w sobie i wobec grupy (innych wychowawców, rodziców, kierownictwa), a jednocześnie uczestniczyć $\mathrm{w}$ procesie podzielania wyobrażeń. $\mathrm{W}$ toku badania-działania realizowany był cel pozwalający opracować projekt koncepcji pedagogicznej placówki. To projekt pedagogiczny, który jest dokumentem ,żywym”, cechuje się pewną elastycznością przy zachowaniu zasadniczych ram. Umożliwia/zobowiązuje do podejmowania refleksji nad działaniem, pobudzania wyobraźni, wrażliwości, pozwala na prowadzenie zawodowego życia społecznego w trakcie pracy, czyli spotkań innych niż dotychczas, podczas których wychowawcy skoncentrowani są na omawianiu spraw wychowania.

Projekt pedagogiczny sprzyja pielęgnowaniu autonomii wychowawcy przede wszystkim dlatego, że jest wytworem wychowawców zaangażowanych w jego opracowywanie $^{51}$. Autonomia jednostki stanowi jedną z ważnych kwestii w projektowaniu zmian. Lionel Bellenger, Marie-Josée Couchaere ${ }^{52}$ wskazują, że projekt stymuluje autonomię jednostki i ujawnia siłę danego zespołu pedagogicznego, zdolność do partycypacji, mediacji, negocjacji jego uczestników. Pozwala przekraczać siebie, swoje dotychczasowe możliwości, podejmować ryzyko porażki, stawiać pytania. Buduje świadomość odpowiedzialności każdego uczestnika i oparcia w grupie.

Autonomia wychowawcy określona jest zatem teoretycznymi ramami działania wychowawczego. Kategoria - towarzyszenie w rozwoju - wskazuje koncepcję wychowania proponowaną przez pedagogikę społeczną, określony kierunek myślenia o wychowaniu. Można ją charakteryzować zarówno z punktu widzenia

${ }^{49}$ H.-H. Krüger, Wprowadzenie $w$ teorie $i$ metody badawcze nauk o wychowaniu, GWP, Gdańsk 2005, s. 148-154.

${ }^{50}$ L. Telka, Badanie - działanie - ksztatcenie w toku interwencji w placówce, [w:] E. Marynowicz-Hetka, E. Skoczylas-Namielska (red.), Pedagogika społeczna. Wstęy i kontynuacje, Wydawnictwo Uniwersytetu Łódzkiego, Łódź 2015, s. 239-256.

${ }^{51}$ L. Telka, Przeksztatcanie przestrzeni społecznej placówki...

${ }^{52}$ L. Bellenger, M.-J. Couchaere, Animer et gerer un projet. Un concept et des outils pour anticiper l'action et la future, ESF, Paris 1999. 
poziomych relacji z wychowankiem, jak i narzędzi, którymi dysponuje wychowawca, sposobności do analizowania zdarzeń z pola praktyki w zespole pedagogicznym konstytuowanym przez pracowników placówki, by te poziome relacje z wychowankiem kształtować i podtrzymywać.

\section{Ku wspólnocie myślenia o autonomii dorosłego i dziecka}

Osiagnięcia pracowników żłobków w wielkim mieście, wyartykułowane w takim dokumencie, jak projekt pedagogiczny, opracowany przez pracowników każdej z 30 placówek, wyprzedzają obowiązujące krajowe akty normatywne. Zawierają poglądy, słownictwo oddalające, sensownie jak się wydaje, także na podstawie analizy koncepcji wychowania w innych krajach, od dydaktycznych zamierzeń wobec dziecka do 3. roku życia w placówce. W łódzkich żłobkach widoczna jest spójność pomiędzy teoretycznymi postulatami wychowania w wolności a przyjętą orientacją działań wychowawczych realizowaną w polu praktyki oraz jej składnikami dotyczącymi warsztatu pracy wychowawcy.

Po innowacji czas na pielęgnowanie osiągnięć, podzielanych wyobrażeń, podtrzymywanie efektów „dobrej roboty” i wspólnie określonych poglądów na wychowanie. Na przykład projekt pedagogiczny zawiera sformułowane przez wychowawców zobowiązanie do analizowania pola swojej praktyki. Izabela Kamińska ${ }^{53}$ wydobyła z poglądów Ireny Lepalczyk jej przekonanie, że przekształcanie przestrzeni społecznej może dokonywać się dzięki ludziom utożsamiającym się z ideą mającą moc. Wydaje się, że propozycja pedagogiki społecznej - towarzyszenie w rozwoju - daje przekonanie, że warto było wyrazić zgodę na zmienianie koncepcji działań wychowawczych i ich urzeczywistnianie w działaniu.

Francis Imbert ${ }^{54}$ zaznacza kruchość wspólnoty wyrażonej podzielaniem poglądów na wychowanie. Wspólnota myślenia o wychowaniu stanowi dorobek pracowników żłobków, efekt kilkuletniego uczestniczenia w przekształcaniu przestrzeni społecznej placówki, a w szczególności przekształcaniu wyobrażeń o wychowanku i wychowawcy oraz relacjach pomiędzy nimi. Wspólnota ta wymaga pielęgnowania, dbałości, by istniała, by dawano sobie radę z tym, że koncepcja wychowania nie daje gotowych odpowiedzi, gotowej metodyki postępowania.

Elżbieta Wołodźko ${ }^{55}$, w refleksji nad edukacyjną propozycją autonomicznego studiowania, realizowaną wraz ze studentami poprzez badanie-działanie,

${ }^{53}$ I. Kamińska, Relacja mistrz-uczeń: próba interpretacji na podstawie refleksji nad autobiografiq naukowa Ireny Lepalczyk, [w:] E. Marynowicz-Hetka, E. Skoczylas-Namielska (red.), Pedagogika społeczna. Wstępy i kontynuacje, Wydawnictwo Uniwersytetu Łódzkiego, Łódź 2015, s. 151.

${ }^{54}$ F. Imbert, Vers une clinique du pédagogie..., s. 238-241.

${ }^{55}$ E. Wołodźko, Ku autonomii studiowania. Procesy, znaczenie, konteksty, zmiana, Wydawnictwo Uniwersytetu Warmińsko-Mazurskiego, Olsztyn 2013, s. 358-359. 
wskazuje proces tworzenia się wspólnoty uczestników tego projektu edukacyjnego. Pokazane przez autorkę cechy owej wspólnoty pozwalają spożytkować je dla opisu prezentowanego w artykule przypadku pracowników żłobków, którzy:

- stali się autorami zmiany (zwłaszcza liderzy) swoich przekonań i przestrzeni społecznej, w której działają dla dziecka i z dzieckiem;

- stawali się stopniowo ,złożonym z różnych elementów, organizmem, zróżnicowanym wewnętrznie, ale zachowującym spójność i integralność" ${ }^{56} \mathrm{~W}$ odniesieniu do nowych poglądów na wychowanie, mimo utrzymujących się także innych, wcześniejszych lub niezdecydowanych poglądów;

- odnajdywali się we wzrastającej samorządności, zwłaszcza w toku opracowywania projektu pedagogicznego, jego uzupełniania, spożytkowania jako narzędzia orientującego działania wychowawcze;

- umacniali swoje poczucie „kompetencji i sprawstwa”, kształtowali swoje przekonania o możliwości i efektywności dokonywanych zmian w polu praktyki, badali je;

- konstytuowali zespół pedagogiczny, sprzyjający „zróżnicowanym wymiarom uczenia się ${ }^{57} \mathrm{w}$ toku realizacji działań wychowawczych, podejmowali zobowiązanie refleksji nad działaniem.

\section{Zakończenie}

Dziecko, przebywające w warunkach tworzonych przez wychowawcę, z perspektywy koncepcji towarzyszenia w rozwoju ma sposobność do spożytkowania tych warunków na swój sposób (wybór czasu, miejsca, zabawki), podzielania swoich doświadczeń z innymi dziećmi i z dorosłymi, bycia zauważonym i pozostania w usankcjonowanej samotności (np. gdy aktywność wymaga koncentracji dziecka, nie wymaga natomiast interwencji wychowawcy). Warunki rozwoju dziecka proponowane przez niedyrektywną koncepcję wychowania pozwalają mu wyrażać swoje doświadczenia, przeżycia kształtowane w rodzinie, środowisku lokalnym. Wychowawca uczy się akceptować doświadczenia, które dziecko zdobywa nie tylko w placówce.

Pożytki, wynikające z koncepcji wychowania - towarzyszenie w rozwoju - dla dziecka, dotyczą tezy wskazanej na początku artykułu, mianowicie wychowawca uzgadnia w odniesieniu do projektu pedagogicznego możliwość swojego działania jako bycie „obok” dziecka, z dzieckiem i dla niego, odpowiadając na jego oczekiwania, możliwości rozwoju, wzajemne poznawanie się.

\footnotetext{
56 Tamże, s. 360.

57 Tamże, s. 361.
} 
Autonomia wychowawcy może zostać opisana jako związek współzależności i niezależności ${ }^{58}$. Współzależność w relacji z innymi wychowawcami dokonuje się w procesie podzielania koncepcji wychowania. Niezależność ujawniana jest w relacji z innymi, z wychowawcami, gdy trzeba analizować, szczerze i uczciwie, zdarzenia z pola praktyki oraz z dzieckiem, gdy trzeba angażować się w sztukę wychowania, podejmować decyzje o działaniu lub powstrzymaniu się od interwencji, wspierać autonomię dziecka.

\section{Bibliografia}

Bellenger L., Couchaere M.-J., Animer et gerer un projet. Un concept et des outils pour anticiper l'action et la future, ESF, Paris 1999.

Bińczycka J., Korczakowska pedagogika emancypacyjna, [w:] B. Śliwerski (red.), Nowe konteksty (dla) edukacji alternatywnej XXI wieku. Idee - Metody - Inspiracje, Oficyna Wydawnicza „Impuls”, Kraków 2001.

Bińczycka J., Między swobodq a przemocq w wychowaniu, Oficyna Wydawnicza „Impuls”, Kraków 2005.

Cyrański B., Aksjologiczne podstawy pedagogiki Heleny Radlińskiej. Przykład zastosowania interpretacji hermeneutycznej, Wydawnictwo Uniwersytetu Łódzkiego, Łódź 2012.

Gribble D., Edukacja w wolności. W poszukiwaniu idealnego systemu ksztatcenia, Oficyna Wydawnicza „Impuls”, Poznań-Kraków 2005.

Hoffmans-Gosset M.-A., Apprendre l'autonomie. Apprendre la socialisation, Chronique Sociale, Lyon 2000.

Imbert F., Vers une clinique du pédagogie. Un itinéraire en science de l'éducation, Éditions Matrice, Vigneux 1992.

Kamińska I., Relacja mistrz-uczeń: próba interpretacji na podstawie refleksji nad autobiografiq naukowa Ireny Lepalczyk, [w:] E. Marynowicz-Hetka, E. Skoczylas-Namielska (red.), Pedagogika społeczna. Wstępy i kontynuacje, Wydawnictwo Uniwersytetu Łódzkiego, Łódź 2015.

Kolankiewicz M. (red.), Pielęgnacja niemowlat i małych dzieci w placówkach opiekuńczych, Dom Małych Dzieci im. Ks. G. P. Baudouina i Wydawnictwo „Żak”, Warszawa 1998.

Krüger H.-H., Wprowadzenie w teorie i metody badawcze nauk o wychowaniu, GWP, Gdańsk 2005.

Kwiatkowska H., Tożsamość nauczycieli. Między anomiq i autonomiq, GWP, Gdańsk 2005.

Maj A., Koncepcja edukacji przedszkolnej w Reggio Emilia we Włoszech, [w:] Z. Melosik, B. Śliwerski (red.), Edukacja alternatywna w XXI wieku, Oficyna Wydawnicza „Impuls”, PoznańKraków 2010.

Muszyńska E., Swoboda, przymus i przemoc w relacjach dziecko-dorosty, Wydawnictwo Naukowe UAM, Poznań 1998.

Obuchowski K., Od przedmiotu do podmiotu, Akademia Bydgoska, Bydgoszcz 2001.

Ollivier B., Autonomie, [w:] J. Barus-Michel, E. Enriquez, A. Levy (red.), Vocabulaire de psychologie. Références et positions, Erés, Ramonville Saint-Agne 2002.

Pacholczyk M., Edukacja w żłobkach w San Miniato jako przestrzeń rozwoju społecznego dzieci oraz wspótpracy z rodzicami i środowiskiem lokalnym, „Problemy Wczesnej Edukacji” 2012, nr 4.

Petiau A., Pourtau L., Une autonomie polysémique. Réflexion á partir d'une recherche-action sur l'accès aux droit et aux soins des squatters, „Vie Sociale” 2012, nr 1, Autonomie et contrôle social. Mythe et réalité.

${ }^{58}$ Tamże, s. 359. 
Radlińska H., O wartości życia ludzkiego. (Odczyt wygłoszony w Polskim Radio), Warszawa 1947. Radlińska H., Pedagogika społeczna, Ossolineum, Wrocław-Warszawa-Kraków 1961.

Radlińska H., Rodzina i świat społeczny, Odbitka z „Polskiej Oświaty Pozaszkolnej” 1932, nr 6, Warszawa 1933.

Rudnicki P., Oblicza buntu w biografiach kontestatorów: refleksyjność, wyzwalajace uczenie się, zmiana, Wydawnictwo Naukowe Dolnośląskiej Szkoły Wyższej, Wrocław 2009.

Szumlewicz K., Emancypacja przez wychowanie, czyli edukacja do wolności, równości i szczęścia, GWP, Sopot 2011.

Telka L., Badanie - działanie - kształcenie w toku interwencji w placówce, [w:] E. Marynowicz-Hetka, E. Skoczylas-Namielska (red.), Pedagogika społeczna. Wstęy i kontynuacje, Wydawnictwo Uniwersytetu Łódzkiego, Łódź 2015.

Telka L., Przekształcanie przestrzeni społecznej placówki. Studium społeczno-pedagogiczne na przykładzie żłobków, Wydawnictwo Uniwersytetu Łódzkiego, Łódź 2009.

Telka L., Współdziałanie wychowawców z badaczem - propozycja refleksji nad działaniem wychowawczym, [w:] H. Gajdamowicz, E. Płóciennik (red.), Teoria pedagogiczna w stużbie praktyki. Praktyka inspiracja dla teorii, Wyższa Szkoła Informatyki i Umiejętności, Łódź 2015.

Theiss W., Radlińska, Wiedza Powszechna, Warszawa 1984.

Walczak A., Spotkanie z wychowankiem. Ku tożsamości ipse pedagoga, Wydawnictwo Uniwersytetu Łódzkiego, Łódź 2011.

Wołodźko E., Ku autonomii studiowania. Procesy, znaczenie, konteksty, zmiana, Wydawnictwo Uniwersytetu Warmińsko-Mazurskiego, Olsztyn 2013.

Woronowicz W., Podstawy refleksyjne edukacji opiekuńczo-wychowawczej, Wyższa Szkoła Pedagogiczna, Słupsk 1998. 